\title{
Perhutanan Sosial di Indonesia dalam Perspektif Islam
}

\author{
Gamin $^{1 *}$ \\ ${ }_{1}^{1}$ Pusat Pendidikan dan Pelatihan Sumber Daya Manusia Lingkungan Hidup dan Kehutanan, Bogor, Jawa Barat, Indonesia
}

\section{ARTICLE INFO}

\section{Keywords}

Land access, social forestry, community welfare, forest sustainability, conflict-tenure.

\section{*Correspondence} gamingessa@gmail.com

\section{Article History}

Received 23 April 2018

Accepted 12 November 2018

Published online 29 Maret 2019

\begin{abstract}
Indonesia adalah negara pertanian dengan jumlah petani mencapai $44 \%$ dari total angkatan kerja atau sekitar 46,7 juta jiwa pada tahun 2009. Pada 2014 lahan pertanian yang tersedia sekitar 41,5 juta hektar sementara $63 \%$ wilayah adalah kawasan hutan. Luas lahan petani pada tahun 2017 rata-rata 0,36 hektar. Hal ini mendorong tingginya kemiskinan Indonesia yang tinggi dengan penduduk miskin sebanyak 27,77 juta orang atau 10,64 \% dari jumlah total penduduk. Indek Pembangunan Manusia pada level 0,685 (kategori menengah). Upaya peningkatan kesejahteraan masyarakat dilakukan melalui pelibatan masyarakat dalam pengelolaan hutan. Praktek perhutanan sosial telah dimulai sejak tahun 1982 dengan berbagai perubahan skema. Program perhutanan sosial berdasarkan kebijakan yang ada sejak tahun 2007 hingga 2016 adalah Pengelolaan Hutan Berbasis Masyarakat, Hutan Desa, Hutan Kemasyarakatan, Hutan Tanaman Rakyat, dan Kemitraan, serta Hutan Adat. Perhutanan sosial dirasakan dapat meningkatkan pendapatan baik yang telah dirasakan maupun yang masih potensial di lapangan. Secara kelestarian hutan, perhutanan sosial dapat meningkatkan variasi jenis tanaman dan meningkatkan penutupan lahan. Perhutanan sosial juga dapat mengurangi konflik tenurial melalui penyerapan tenaga kerja, pemberian rasa aman dan pemberian ketenangan berusaha pada kawasan hutan. Pendampingan kepada pelaku perhutanan sosial dan pemastian tidak terjadi pemindahan hak kelola merupakan pelajaran penting dari penelitian ini.
\end{abstract}

\begin{abstract}
Indonesia is an agricultural country with a number of farmers reaching $44 \%$ of the total workforce or around 46.7 million in 2009. In 2014 the available agricultural land was around 41.5 million hectares while 63\% of the area was forested. The land area of farmers in 2017 averages 0.36 hectares. This has led to a high rate of Indonesian poverty with a poor population of 27.77 million people or $10.64 \%$ of the total population. Human Development Index at level 0.685 (middle category). Efforts to improve community welfare are carried out through community involvement in forest management. Social forestry practices have been started since 1982 with various schema changes. Social forestry programs based on existing policies from 2007 to 2016 are Community Based Forest Management, Village Forests, Community Forests, Community Plantation Forests, and Partnerships, and Customary Forests. Social forestry is felt to be able to increase both perceived and potential income in the field. In terms of forest sustainability, social forestry can increase variety of crops and increase land cover. Social forestry can also reduce tenurial conflicts through labor absorption, providing security and providing business peace in the forest area. Assistance to social forestry actors and ensuring that there is no transfer of management rights is an important lesson from this research.
\end{abstract}

\section{PENDAHULUAN}

Luas kawasan hutan daratan di Indonesia mencakup 120, 77 juta hektar (BPS, 2017) atau sekitar 63 prosen dari luas daratan Indonesia yang berjumlah 192,26 juta hektar (Badan Informasi Geospasial, 2013). Sebanyak 37\% daratan selain kawasan hutan dihuni oleh sekitar 254,9 juta jiwa (Anton, 2015) sehingga rasio kepemilikan lahan di Indonesia adalah 0.28 hektar per orang. Mata pencaharian penduduk sebagian besar adalah pertanian dengan jumlah petani mencapai $44 \%$ dari total angkatan kerja Indonesia atau sekitar 46,7 juta jiwa (BPS, 2009). Indek pembangunan manusia indonesia saat ini berada pada level 0,685 yang menempatkan Indonesia dalam kategori pembangunan manusia menengah, dan peringkat 113 dari 188 negara dan wilayah (UNDP, 2017) dengan penduduk miskin sebanyak 27,77 juta orang (10,64 persen dari jumlah total penduduk) (Destrianita, 2017). Salah satu pendorong kemiskinan ini adalah rendahnya produktivitas pertanian sebagai akibat sempitnya lahan pertanian yang hanya 41.5 juta hektar (BPS, 2014) yang menyusut 100 ribu hektar setiap tahunnya (Astuti, 2016). Saat ini luas rata-rata 
kepemilikan lahan petani di Indonesia hanya 0,36 hektare lebih rendah dari Vietnam dan Thailand yang sudah lebih dari satu hektare (Abdullah, 2017). Sempitnya lahan pertanian yang kontradiktif dengan meningkatnya jumlah penduduk mengakibatkan lahan menjadi barang yang semakin langka dan bernilai strategis. Kepemilikan lahan petani yang minim berimplikasi produktivitas rendah sehingga berdampak kesejahteraan petani (Abdullah, 2017). Kelangkaan lahan yang semakin terjadi dan kebutuhan lahan yang semakin tinggi mengakibatkan aktivitas pemanfaatan, sebagian secara tidak sah, lahan kawasan hutan negara oleh penduduk. Konflik tenurial kawasan hutan diberbagai tempat sulit dihindarkan hingga periode pemerintahan saat ini.

Kajian terhadap praktek perhutanan sosial telah banyak dilakukan baik di luar maupun di dalam negeri. Perhutanan sosial, sebagaimana catatan para peneliti, memberikan dampak terhadap lingkungan, ekonomi dan sosial. Catatan lain, perhutanan sosial dilakukan sebagai salah satu langkah untuk menyelesaikan konflik tenurial kawasan hutan.

Praktek perhutanan sosial di Indonesia telah ada sejak tahun 1982 dengan program Mantri-Lurah, Pemberdayaan Masyarakat Desa Hutan-PMDH, Pengelolaan Sumber Daya Hutan Bersama Masyarakat-PHBM (Perhutani, 2016). Pada masa reformasi 1997/1998 terbit Undang-undang No.41/1999 tentang Kehutanan yang kemudian diatur tentang penyelenggaraan hutan kemasyarakatan pada 2001 dan pemberdayaan masyarakat dalam rangka social forestry pada tahun 2004. Periode 20042016 skema perhutanan terdiri atas empat jenis, yakni: Hutan Kemasyarakatan (HKm), Hutan Desa (HD), Hutan Tanaman Rakyat (HTR), dan Kemitraan. Pada tahun 2016 melalui Peraturan Menteri LHK No.83 (P.83), perhutanan sosial diwujudkan dalam skema Hutan Kemasyarakatan (HKm), Hutan Desa (HD), Hutan Tanaman Rakyat (HTR), dan Kemitraan serta Hutan Adat.

Secara konseptual, hasil perhutanan sosial memberikan pengaruh positif terhadap lingkungan (Thompson, 1999), (Singh K. , 2000), terhadap ekonomi kesejahteraan (Djamhuri, 2008), (Nasir, Saleh, \& Bahruni, 1997). Hasil perhutanan sosial berpengaruh terhadap ekologi, ekonomi dan sosial sekaligus dilaporkan oleh (Singh, Mahankuda, Dolai, Behera, \& Choudhury, 2016). Perhutanan sosial juga tercatat oleh para peneliti sebagai upaya untuk menyelesaikan konflik (Kant \& Cooke, 1999), (Hayami \& Otsuka, 1993), (Hu, 1997) (Handoyo, Suka, \& Ginoga, 2011), (Kartodihardjo, 2011), (Gamin., Nugroho, Kartodihardjo, Kolopaking, \& Boer, 2014) dan (Khan, 1998).

Dari fakta-fakta yang diuraikan di atas, perhutanan sosial yang dilakukan adalah dalam rangka memberikan akses masyarakat terhadap kawasan hutan yang diyakini dapat memberikan manfaat ekonomi, ekologi, dan sosial, serta sebagai upaya untuk mengurangi / menyelesaikan konflik terurial kawasan hutan. Pemerintahan Indonesia periode 2014-2019 menargetkan alokasi perhutanan sosial seluas 12,7 juta hektar area hutan (PSKL, 2017). Perkembangan akses 12,7 juta hektar hutan untuk dikelola masyarakat tersebut melalui perhutanan sosial hingga saat ini adalah hal yang perlu dikawal dan dicermati. Hal ini mengingat distribusi 12,7 juta hektar ini ditargetkan selesai dalam 4 tahun yakni pada tahun 2019. Sementara target periode lima sebelumnya hanya 2,5 juta hektar. Tulisan ini menguraikan dinamika perkembangan perhutanan sosial di Indonesia, dampaknya terhadap kesejahteraan dan pengurangan konflik tenurial kawasan hutan, serta telisik praktek perhutanan sosial dari sudut pandang Islam. Dinamika perhutanan sosial diuraikan terkait kebijakan, program, target dan capaian, peran perhutanan sosial dalam meningkatkan kesejahteraan masyarakat dan konflik tenurial, faktor penghambat dan pendukung perhutanan sosial, dan diakhiri dengan pandangan Islam terhadap perhutanan sosial di Indonesia.

\section{METODE PENELITIAN}

\subsection{Pendekatan Penelitian}

Penelitian ini dilaksanakan dengan menggunakan metode deskriptif kualitatif. Pengertian deskriptif adalah metode yang berfungsi mendeskripsikan atau memberi gambaran terhadap obyek yang diteliti melalui data atau sampel yang terkumpul sebagaimana adanya, tanpa melakukan analisis dan membuat kesimpulan yang berlaku umum (Sugiyono, 2010). Metode penelitian kualitatif menurut Bogdan dan Taylor (Moleong, 2011) adalah prosedur penelitian yang menghasilkan data deskriptif berupa kata-kata tertulis atau lisan dari orang-orang dan perilaku yang dapat diamati.

\subsection{Pengumpulan Data}

Data-data yang dikumpulkan dalam penelitian ini terdiri atas data perkembangan perhutanan sosial, data dampak perhutanan sosial, informasi lain yang relevan, dan data lapangan tambahan untuk memperkaya informasi terhadap penelitian ini.

a. Data perkembangan perhutanan sosial dari kebijakan hingga program dan hasilnya diperoleh dari kantor pusat Kementerian Lingkungan Hidup dan Kehutanan di Jakarta maupun informasi dari website resmi. Situs resmi Perum Perhutani juga merupakan sumber informasi hasil penelitian ini.

b. Data dampak perhutanan sosial terhadap kesejahteraan dan penyelesaian konflik tenurial kawasan hutan akan diperoleh dari anggota Hutan Kemasyarakatan di Desa Sukakarya dan anggota Hutan Desa di Desa Muara Megang I, serta KPH Lakitan di kabupaten Musi Rawas Sumatera Selatan sebagai suatu kasus (Gambar 1). Pemilihan KPH Lakitan sebagai studi kasus pada penelitian ini mengingat: 1) lokasi tersebut telah memilih skema perhutanan sosial yakni HKm dan HD pada tahun 2014 sebagai upaya penyelesaian konflik dan telah memegang ijin usaha pada tahun 2015 (Gamin., Nugroho, Kartodihardjo, Kolopaking, \& Boer, 2014), 2) komunikasi dengan pengurus kedua kelompok serta kepala Kesatuan Pengelolaan Hutan Lakitan yang terkait dengan kedua kelompok tersebut masih terjalin cukup baik.

c. Informasi lain yang relevan juga diperoleh dari Pengelola Hutan Desa Campursari yang terletak tidak jauh dari desa Muara Megang I.

d. Data pengamatan lapangan tambahan diperoleh dari wilayah Teluk Jambe Kabupaten Karawang Jawa Barat wilayah kerja Perum Perhutani.

Penelitian dilaksanakan mulai pada bulan Juni hingga September 2017. Observasi praktek perhutanan sosial di wilayah Teluk Jambe dilaksanakan pada bulan Juni 2017. Penelusuran dokumen produk kebijakan, hasil kebijakan, dan kunjungan ke kantor Direktorat Jenderal Perhutanan Sosial dan Kemitraan Lingkungan Kementerian Lingkungan Hidup dan Kehutanan di Jakarta dilaksanakan mulai awal Agustus 2017. Penggalian data lapangan pada lokasi studi dilaksanakan pada akhir Agustus 2017. Pengolahan data, analisis data dan penulisan laporan pada minggu pertama dan kedua September 2017. 
Teknik pengumpulan data akan dilakukan studi dokumen, wawancara, dan observasi/pengamatan lapangan. Penentuan informen dilakukan dengan teknik Snowball Sampling yakni mengikuti informasi informan sebelumnya untuk menentukan informan berikutnya (Sugiyono 2010) dan informen kunci ditentukan secara sengaja (purposive) berdasarkan kriteria keterperolehan data.

Kriteria unit informasi yang diperkirakan dapat menjawab data yang dibutuhkan adalah: a) mengetahui strategi pelaksanaan kebijakan Perhutanan Sosial (PS) dan penyelesaian konflik, mengetahui pelaksanaan program Hutan Desa (HD) dan hasilhasilnya, mengetahui pelaksanaan program Hutan Kemasyarakatan (HKm) dan hasil-hasilnya, mengetahui pelaksanaan program HA dan hasil-hasilnya, mengetahui pelaksanaan program Hutan Tanaman Rakyat (HTR) dan hasil-hasilnya, serta mengetahui pelaksanaan program Hutan Rakyat (HR) dan hasil-hasilnya.

Terkait dampak perhutanan sosial, kriteria unit informasi yang dibutuhkan adalah mengetahui hasil HKm saat ini dibandingkan dengan tahun 2015 dan sebelumnya, mengetahui hasil HD Muara Megang I saat ini dibandingkan dengan tahun 2015 dan sebelumnya, dan mengetahui rencana jangka panjang, rencana jangka pendek wilayah KPHP Lakitan dan perkembangan $\mathrm{HKm}$ dan HD pada wilayahnya. Informen dari kasus lapangan diharapkan dapat memberikan infomasi mengenai kondisi kesejahteraan dan kondisi konflik sebelum adanya kegiatan perhutanan sosial sebelum 2014 dan kondisi saat ini 2017.

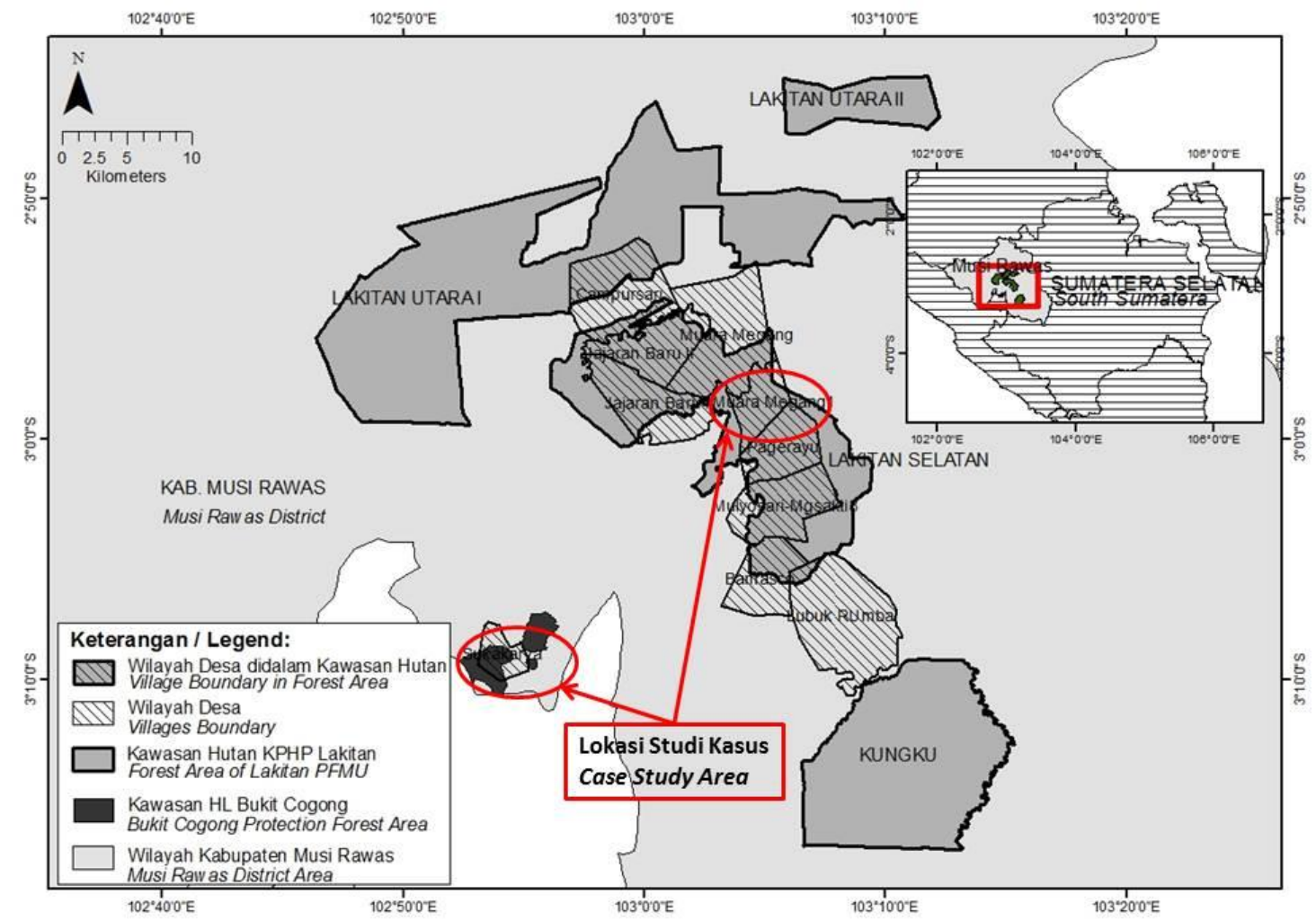

Sumber: (Gamin., Nugroho, Kartodihardjo, Kolopaking, \& Boer, 2014); (Pemprov Sumsel, 2015). Gambar 1. Lokasi Penelitian

Data kebijakan tertulis ditelusuri dari perpustakaan dan laman kementerian LHK. Data Program-program PS dan Hasilhasilnya diperoleh dari kantor Direktur Penyiapan Kawasan Perhutanan Sosial. Data peningkatan kesejahteraan, dampak terhadap konflik lahan diperoleh informasi dari Pak Amrin (HD Ds. Muara Megang 1-Sumsel), Pak Nibuansyah (HKm di Bukit Cogong Sukakarya-Sumsel), dan Edi Cahyono, S.Hut, M.Si (KKPH Lakitan, Sumsel) sebagai informen awal. Informen lain adalah pengurus HD Muara Megang I, perangkat desa Muara Megang I, dan pengurus HD Campursari.

\subsection{Analisis Data}

Analisis penelitian ini secara keseluruhan adalah kualitatif yakni analisis data yang dilakukan dengan proses: 1)mengumpulkan data mentah, 2)membuat transkrip data, 3)membuat tabulasi data, 4)membuat kesimpulan sementara, 5)melakukan validasi (triangulasi), dan 6)membuat kesimpulan akhir.

Data yang dianalisis akhir pada penelitian ini adalah peningkatan kesejahteraan setelah adanya program perhutanan sosial, serta pengurangan konflik setelah diselesaikan melalui perhutanan sosial. Kesejahteraan dilihat dari indikator kesejahteraan yakni pendapatan keluarga. Pengurangan konflik yang terjadi akibat adanya program perhutanan sosial dianalisis dari informasi yang diperoleh dari informen penelitian. Hal ini dilihat dari luas lahan yang berkonflik, eskalasi konflik yang ada, gaya sengketa para pihak, kepastian hak atas lahan, serta hubungan para pihak. 


\section{HASIL DAN PEMBAHASAN}

\subsection{Kebijakan-kebijakan Pemerintah Terkait Perhutanan Sosial}

Pemerintahan Indonesia periode 2014-2019 yang dipimpin Jokowi-JK mencanangkan 9 (sembilan) "Nawa Cita" untuk mewujudkan "Indonesia Yang Berdaulat, Mandiri dan Berkepribadian Berlandaskan Gotong Royong". Lima dari sembilan "Nawa Cita" tersebut terkait dengan lingkungan hidup dan kehutanan (Nurbaya, 2015). Dua dari lima "Nawa Cita" yang terkait lingkungan hidup dan kehutanan terkait langsung dengan kesejahteraan masyarakat, yakni: 1)membangun Indonesia dari pinggiran, dan 2) meningkatkan kualitas hidup manusia Indonesia. Membangun desa dari pinggiran dilakukan dengan melakukan pembangunan pedesaan yang perlu diwujudkan melalui: a) jaminan hak desa untuk mengelola skala lokal mendukung pengentasan 5000 desa tertinggal dan 2000 desa mandiri, serta b) pemberian akses 12,7 juta hektar hutan yang dikelola masyarakat dalam bentuk HKm, HD, HTR, kemitraan, dan HA. Dalam hal meningkatkan kualitas hidup manusia Indonesia ingin diwujudkan adanya "Peningkatan Kesejahteraan Rakyat Marjinal Melalui Pelaksanaan Indonesia Kerja" yang dapat dilakukan melalui "Identifikasi Kawasan Hutan" guna melakukan "Redistribusi tanah dan legalisasi aset". Pemerintah Indonesia telah menargetkan alokasi perhutanan sosial seluas 12,7 juta hektar areal hutan (PSKL, 2017). Target ini dipandang cukup ambisius bila dibandingkan target periode lima tahun sebelumnya yang hanya 2,5 juta hektar.

Kebijakan terkait perhutanan sosial ditemukan mulai peraturan yang dikeluarkan oleh Perum Perhutani hingga kebijakan yang dikeluarkan Kementerian Lingkungan Hidup dan Kehutanan. Perhutani telah beroperasi sejak tahun 1972 sementara Departemen Kehutanan mulai berdiri sejak tahun 1983. Perum Perhutani adalah pengelola hutan produksi dan hutan lindung di Pulau Jawa sementara Departemen Kehutanan, yang sekarang bernama Kementerian Lingkungan Hidup dan Kehutanan, mengelola kawasan hutan seluruh Indonesia. Produk kebijakan perhutanan sosial yang dikeluarkan Perhutani tercatat sebanyak 4 (empat) keputusan Direksi Perum Perhutani (Tabel 1).

Kementerian Kehutanan tercatat mengeluarkan keputusan menteri pada tahun 2001 terkait hutan kemasyarakatan dan satu peraturan menteri pada tahun 2004 terkait pemberdayaan masyarakat. Namun belum ditemukan catatan pencapaian hasil dari kebijakan tersebut (Tabel 1).

Kebijakan perhutanan sosial pada kementerian kehutanan yang tercatat capaiannya adalah pada periode tahun 2007 sampai 2016. Kebijakan tersebut mengatur HKm, HD, HTR dan Kemitraan (Tabel 2). HKm diatur melalui peraturan menteri kehutanan nomor P.37/Menhut-II/2007 sebagaimana diubah dua kali yakni melalui peraturan menteri kehutanan nomor P.13/MenhutII/2010 dan peraturan menteri kehutanan nomor P.52/Menhut-II/2011. Pada tahun 2008 dikeluarkan peraturan menteri kehutanan yang mengatur tentang HD yakni nomor P.49/Menhut-II/2008 yang mengalami dua kali perubahan yakni melalui P.14/Menhut-II/2010, dan P.53/Menhut-II/2011.

HTR adalah hutan tanaman pada hutan produksi yang dibangun oleh perorangan atau koperasi untuk meningkatkan potensi dan kualitas hutan produksi dengan menerapkan silvikultur dalam rangka menjamin kelestarian sumber daya hutan (Permenhut P.23/Menhut-II/2007). Peraturan ini telah mengalami perubahan melalui peraturan menteri kehutanan nomor P.5/MenhutII/2008. Kebijakan yang mengatur Kemitraan adalah Peraturan Menteri Kehutanan (Permenhut) Nomor P.39/Menhut-II/2013 tentang Pemberdayaan Masyarakat Setempat Melalui Kemitraan Kehutanan.

Tahun 2016 diterbitkan Peraturan Menteri Lingkungan Hidup dan Kehutanan Nomor P.83/MENLHK/SETJEN/KUM.1/10/2016 tentang Perhutanan Sosial. Peraturan menteri ini mengatur pemberian akses lahan kepada masyarakat dalam kawasan hutan dalam bentuk HD, HKm, HTR, Kemitraan, HA (Tabel 1). Terakhir menteri lingkungan hidup dan kehutanan mengeluarkan Permenhut No 39/MEN,HK/SETJEN/KUM.1/6/2017 tentang Perhutanan Sosial di Wilayah Kerja Perum Perhutani. 
Tabel 1. Kebijakan terkait perhutanan sosial, program, hasil, dan hambatan

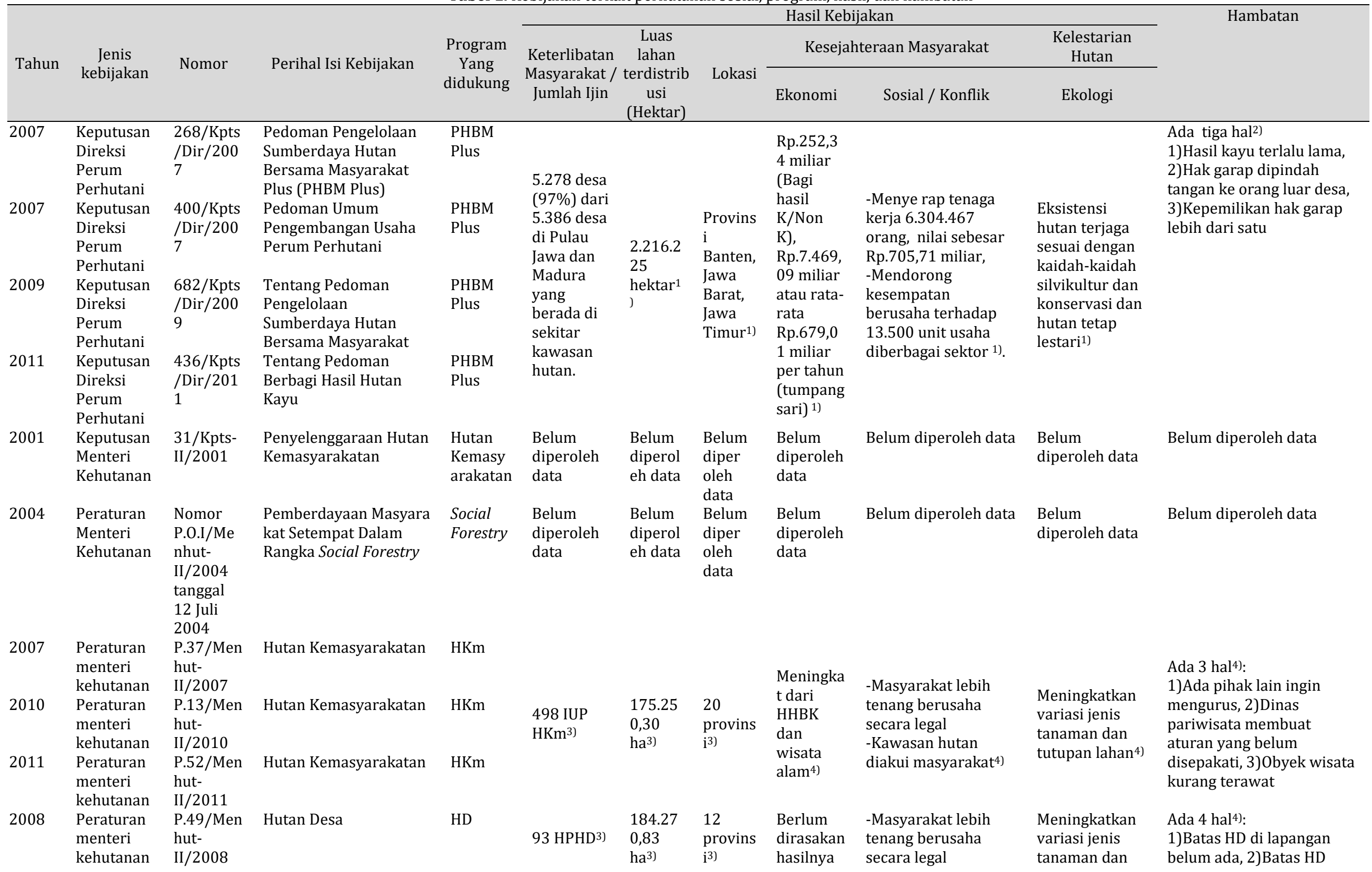




\begin{tabular}{|c|c|c|c|c|c|c|c|c|c|c|c|}
\hline \multirow{3}{*}{ Tahun } & \multirow{3}{*}{$\begin{array}{c}\text { Jenis } \\
\text { kebijakan }\end{array}$} & \multirow{3}{*}{ Nomor } & \multirow{3}{*}{ Perihal Isi Kebijakan } & \multirow{3}{*}{$\begin{array}{l}\text { Program } \\
\text { Yang } \\
\text { didukung }\end{array}$} & \multicolumn{6}{|c|}{ Hasil Kebijakan } & \multirow[t]{3}{*}{ Hambatan } \\
\hline & & & & & \multirow{2}{*}{$\begin{array}{l}\text { Keterlibatan } \\
\text { Masyarakat / } \\
\text { Jumlah Ijin }\end{array}$} & \multirow{2}{*}{$\begin{array}{c}\text { Luas } \\
\text { lahan } \\
\text { terdistrib } \\
\text { usi } \\
\text { (Hektar) }\end{array}$} & \multirow{2}{*}{ Lokasi } & \multicolumn{2}{|c|}{ Kesejahteraan Masyarakat } & \multirow{2}{*}{$\begin{array}{c}\begin{array}{c}\text { Kelestarian } \\
\text { Hutan }\end{array} \\
\text { Ekologi }\end{array}$} & \\
\hline & & & & & & & & Ekonomi & Sosial / Konflik & & \\
\hline 2010 & $\begin{array}{l}\text { Peraturan } \\
\text { menteri } \\
\text { kehutanan }\end{array}$ & $\begin{array}{l}\text { perihal } \\
\text { P.14/Men } \\
\text { hut- } \\
\text { II/2010 }\end{array}$ & Hutan Desa & HD & & & & $\begin{array}{l}\text { baru } 2 \\
\text { tahun } \\
\text { sejak } \\
2015^{4)}\end{array}$ & $\begin{array}{l}\text {-Kawasan hutan } \\
\text { diakui masyarakat4) }\end{array}$ & tutupan lahan4) & $\begin{array}{l}\text { berada di luar wilayah } \\
\text { desa, 3)Batas desa belum } \\
\text { disepakati desa tetangga, } \\
\text { 4)Belum dianggarkan }\end{array}$ \\
\hline 2011 & $\begin{array}{l}\text { Peraturan } \\
\text { menteri } \\
\text { kehutanan }\end{array}$ & $\begin{array}{l}\text { P.53/Men } \\
\text { hut- } \\
\text { II/2011 }\end{array}$ & Hutan Desa & HD & & & & & & & penataan batas HD \\
\hline 2007 & $\begin{array}{l}\text { Peraturan } \\
\text { menteri } \\
\text { kehutanan }\end{array}$ & $\begin{array}{l}\text { P. } 23 / \text { Men } \\
\text { hut- } \\
\text { II/ } 2007\end{array}$ & $\begin{array}{l}\text { Tata Cara Permohonan } \\
\text { Izin Usaha Pemanfaatan } \\
\text { Hasil Hutan Kayu Pada }\end{array}$ & HTR & & & & & & & \\
\hline 2008 & $\begin{array}{l}\text { Peraturan } \\
\text { menteri } \\
\text { kehutanan }\end{array}$ & $\begin{array}{l}\text { P.5/Menh } \\
\text { ut- } \\
\text { II/2008 }\end{array}$ & $\begin{array}{l}\text { Hutan Tanaman Rakyat } \\
\text { Dalam Hutan Tanaman } \\
\text { Tata Cara Permohonan } \\
\text { Izin Usaha Pemanfaatan } \\
\text { Hasil Hutan Kayu Pada } \\
\text { Hutan Tanaman Rakyat } \\
\text { Dalam Hutan Tanaman }\end{array}$ & HTR & $\begin{array}{l}2.781 \\
\text { IUPHHK } \\
\text { HTR }^{3)}\end{array}$ & $\begin{array}{l}203.73 \\
8,34 \\
\text { ha }^{3)}\end{array}$ & $\begin{array}{l}28 \\
\text { provins } \\
\mathrm{i}^{3)}\end{array}$ & $\begin{array}{l}\text { Belum } \\
\text { diperoleh } \\
\text { data }\end{array}$ & Belum diperoleh data & $\begin{array}{l}\text { Belum } \\
\text { diperoleh data }\end{array}$ & Belum diperoleh data \\
\hline 2013 & $\begin{array}{l}\text { Peraturan } \\
\text { Menteri } \\
\text { Kehutanan }\end{array}$ & $\begin{array}{l}\text { P.39/Men } \\
\text { hut- } \\
\text { II/2013 }\end{array}$ & $\begin{array}{l}\text { Pemberdaya an } \\
\text { Masyara kat Setempat } \\
\text { Melalui Kemitraan } \\
\text { Kehutanan. }\end{array}$ & $\begin{array}{l}\text { Kemitra } \\
\text { an }\end{array}$ & $29 \mathrm{MoU}^{3)}$ & $\begin{array}{l}44.010 \\
16^{3)}\end{array}$ & $\begin{array}{l}5 \\
\text { provins } \\
\mathrm{i}^{3)}\end{array}$ & $\begin{array}{l}\text { Belum } \\
\text { diperoleh } \\
\text { data }\end{array}$ & Belum diperoleh data & $\begin{array}{l}\text { Belum } \\
\text { diperoleh data }\end{array}$ & $\begin{array}{l}\text { Belum ada dana di KPH } \\
\text { untuk membeli getah karet } \\
\text { hasil kemitraan5) }\end{array}$ \\
\hline 2016 & $\begin{array}{l}\text { Peraturan } \\
\text { Menteri } \\
\text { Lingkunga } \\
\text { n Hidup } \\
\text { dan } \\
\text { Kehutanan }\end{array}$ & $\begin{array}{l}\text { P.83/ME } \\
\text { NLHK/SE } \\
\text { TJEN/KU } \\
\text { M.1/10/2 } \\
016\end{array}$ & Perhutanan Sosial & $\begin{array}{l}\text { HD, } \\
\text { HKm, } \\
\text { HTR, } \\
\text { Kemitra } \\
\text { an, HA }\end{array}$ & $\begin{array}{l}\text { Belum } \\
\text { diperoleh } \\
\text { data }\end{array}$ & $\begin{array}{l}\text { Belum } \\
\text { diperol } \\
\text { eh data }\end{array}$ & $\begin{array}{l}\text { Belum } \\
\text { dipero } \\
\text { leh } \\
\text { data }\end{array}$ & $\begin{array}{l}\text { Belum } \\
\text { diperoleh } \\
\text { data }\end{array}$ & Belum diperoleh data & $\begin{array}{l}\text { Belum } \\
\text { diperoleh data }\end{array}$ & Belum diperoleh data \\
\hline 2017 & $\begin{array}{l}\text { Peraturan } \\
\text { Menteri } \\
\text { Lingkunga } \\
\text { n Hidup } \\
\text { dan } \\
\text { Kehutanan }\end{array}$ & $\begin{array}{l}\text { P.39/ME } \\
\text { N,HK/SE } \\
\text { TJEN/KU } \\
\text { M.1/6/20 } \\
17\end{array}$ & $\begin{array}{l}\text { Perhutanan Sosial di } \\
\text { Wilayah Kerja Perum } \\
\text { Perhutani }\end{array}$ & $\begin{array}{l}\text { HD, } \\
\text { HKm, } \\
\text { HTR, } \\
\text { Kemitra } \\
\text { an, HA }\end{array}$ & $\begin{array}{l}\text { Belum } \\
\text { diperoleh } \\
\text { data }\end{array}$ & $\begin{array}{l}\text { Belum } \\
\text { diperol } \\
\text { eh data }\end{array}$ & $\begin{array}{l}\text { Belum } \\
\text { dipero } \\
\text { leh } \\
\text { data }\end{array}$ & $\begin{array}{l}\text { Belum } \\
\text { diperoleh } \\
\text { data }\end{array}$ & Belum diperoleh data & $\begin{array}{l}\text { Belum } \\
\text { diperoleh data }\end{array}$ & Belum diperoleh data \\
\hline
\end{tabular}

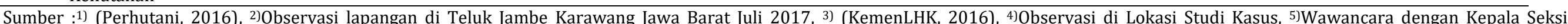
Perlindungan, Pengamanan dan Pemberdayaan Masyarakat KPH Dampelas Tinombo Agustus 2017. 


\subsection{Program-program Perhutanan Sosial}

Program perhutanan sosial di Indonesia tidak dapat terlepas dari program-program yang telah dilakukan oleh Perum Perhutani. Sejak berdirinya tahun 1972, Perhutani telah menerapkan berbagai program yang melibatkan masyarakat dalam pengelolaan hutan (Perhutani, 2016). Program Mantri-Lurah adalah program pertama Perhutani untuk memberdayakan masyarakat. Tahun 1982 program Pembuatan Sarana Prasarana Bio Fisik dalamm Pembangunan Masyarakat Desa. Tahun 1984 Perhutani menggulirkan program Perhutanan Sosial melalui pembentukan Kelompok Tani Hutan (KTH), Agroforesty dan Usaha Produktif. Tahun 1994 perhutanan sosial disempurnakan melalui Pembinaan Masyarakat Desa Hutan Terpadu (PMDHT). Empat tahun kemudian, 1988, dikenal program Pemberdayaan Masyarakat Desa Hutan (PMDH). Pada tahun 2001 PMDH dijadikan sebagai suatu sistem yaitu Pengelolaan Sumber Daya Hutan Bersama Masyarakat (PHBM) dengan prinsip bersama, berdaya, berbagi dan transparant. Pada sistem PHBM, hutan dibagi dalam pangkuan desa. Pada setiap desa dibuat Lembaga Masyarakat Desa Hutan (LMDH) yang berbadan hukum serta memiliki anggaran dasar (AD) dan anggaran rumah tangga (ART). LMDH adalah lembaga resmi sebagai mitra sejajar yang bekerjasama dengan Perum Perhutani dalam mengelola sumber daya hutan.

Sejak era reformasi tahun 1997-1998 konsep baru pembangunan kehutanan di Indonesia lebih berpihak kepada rakyat dan memberi peluang kepada rakyat untuk turut serta dalam pengelolaan hutan. Salah satu wujud kebijakan tersebut adalah social forestry sebagaimana tertuang dalam peraturan Menteri Kehutanan Nomor P.O.I/Menhut-II/2004 yang juga mengakomodir keputusan Menteri Kehutanan No. 31/Kpts-II/2001 tentang Penyelenggaraan Hutan Kemasyarakatan.

Pemberdayaan masyarakat yang ditawarkan pemerintah dalam pengelolaan hutan di Indonesia periode 2004-2016 terdiri atas beberapa jenis program, yakni : HKm, HD, HTR, dan Kemitraan (Tabel 1). Periode setelah tahun 2016 program perhutanan sosial selain HKm, HD, HTR, dan Kemitraan adalah Hutan Adat. Hampir semua skema perhutanan sosial setelah 2016 dipegang hak kelolanya oleh masyarakat secara berkelompok (communal) kecuali HTR yang memungkinkan perorangan memiliki hak kelola (Tabel 2).

Tabel 2. Perbedaan skema perhutanan sosial bds p.83 (1)

\begin{tabular}{|c|c|c|c|c|}
\hline No & Skema & $\begin{array}{l}\text { Tipe/Fungsi } \\
\text { Hutan }\end{array}$ & Pemegang & Sistem tenurial \\
\hline 1 & Hutan Desa & $\begin{array}{l}\text { Hutan Produksi } \\
\text { Hutan Produksi }\end{array}$ & Pemerintah Desa & Hak Pengelolaan \\
\hline \multirow[t]{2}{*}{2} & $\begin{array}{l}\text { Hutan } \\
\text { Kemasyarakatan }\end{array}$ & Hutan Produksi & $\begin{array}{l}\text { Kelompok Tani, Gabungan Kelompok } \\
\text { Tani }\end{array}$ & Ijin Pemanfaatan \\
\hline & & Hutan Lindung & & \\
\hline 3 & $\begin{array}{l}\text { Hutan Tanaman } \\
\text { Rakyat }\end{array}$ & Hutan Produksi & Kelompok Tani, Perorangan & Ijin Pemanfaatan \\
\hline \multirow[t]{3}{*}{4} & Kemitraan & Hutan Produksi & $\begin{array}{l}\text { Masyarakat Lokal + Pemegang Hak } \\
\text { atau Ijin / KPH }\end{array}$ & MoU Kemitraan \\
\hline & & Hutan Lindung & idem & MoU Kemitraan \\
\hline & & Hutan Konservasi & $\begin{array}{l}\text { Masyarakat Lokal + Pengelola (KPH, } \\
\text { BTN, BKSDA, KHDTK, UPTD, } \\
\text { BUMN/D) }\end{array}$ & MoU Kemitraan \\
\hline 5 & Hutan Adat & $\begin{array}{l}\text { H. Produksi, Lin } \\
\text { dung, Konservasi }\end{array}$ & Masyarakat Adat & Hak Pengelolaan \\
\hline
\end{tabular}

Tabel 3. Perbedaan skema perhutanan sosial bds p.83 (2)

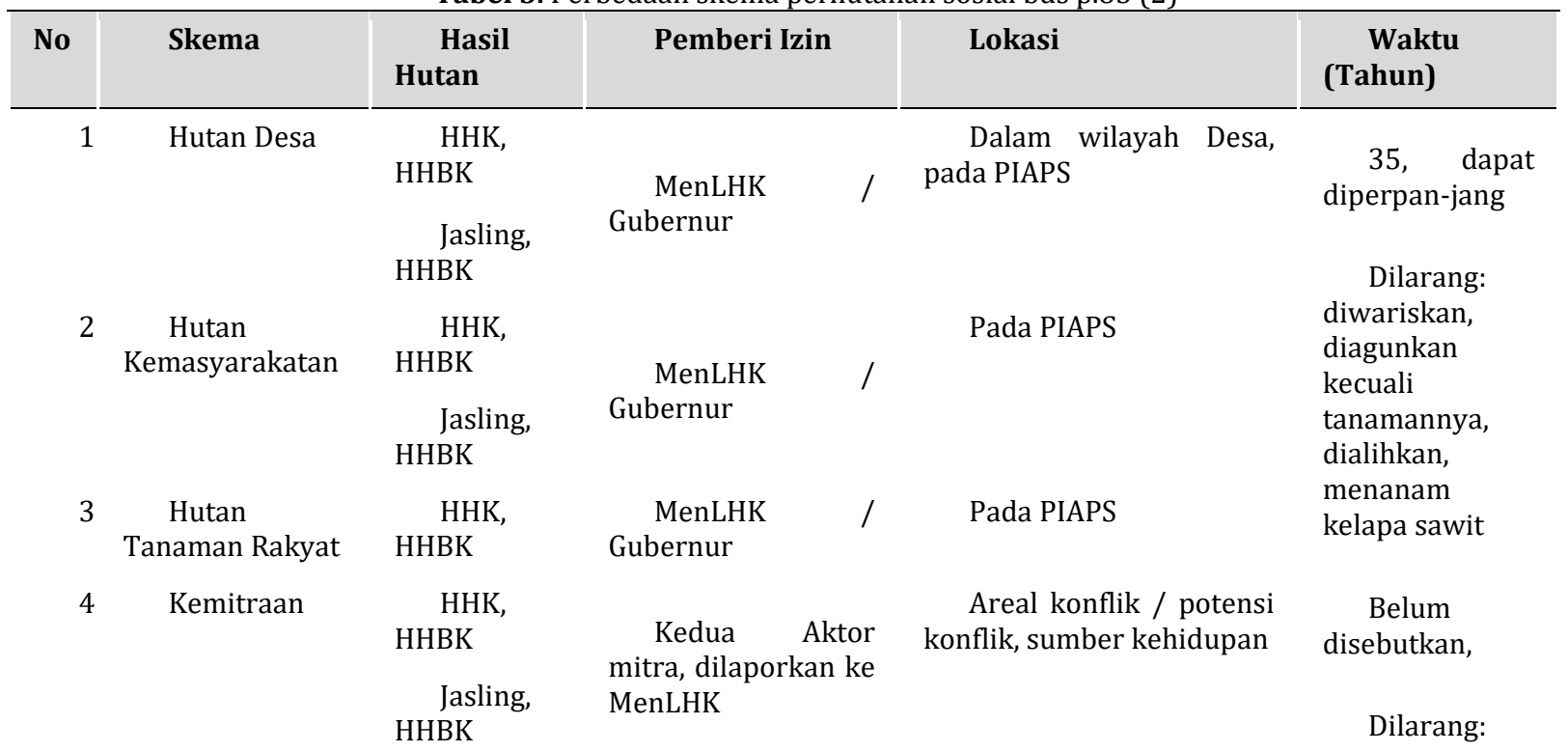


JKPIs, Vol. 2 No. $1,2019 \mid 25$

\begin{tabular}{|c|c|c|c|c|c|}
\hline No & Skema & $\begin{array}{c}\text { Hasil } \\
\text { Hutan }\end{array}$ & Pemberi Izin & Lokasi & $\begin{array}{l}\text { Waktu } \\
\text { (Tahun) }\end{array}$ \\
\hline & & $\begin{array}{c}\text { Jasling, } \\
\text { Wisata Alam }\end{array}$ & & \begin{tabular}{l}
\multicolumn{1}{r}{ Areal konflik / potensi } \\
konflik, sumber \\
kehidupan, \\
terdegradasi, di luar \\
inti Taman Nasional
\end{tabular} & \multirow[t]{2}{*}{$\begin{array}{l}\text { diwariskan, } \\
\text { dipin } \\
\text { dahtangnkan, } \\
\text { diagunkan, } \\
\text { menanam } \\
\text { kelapa sawit }\end{array}$} \\
\hline 5 & Hutan Adat & $\begin{array}{r}\text { Semua, } \\
\text { asal lestari }\end{array}$ & MenLHK & Pada Wilayah Adat & \\
\hline
\end{tabular}

Sumber : (KemenLHK, 2016)

\subsection{Target dan Capaian Perhutanan Sosial Sampai Tahun 2016}

Sejak tahun 2001 sampai tahun 2012, Perhutani menyatakan telah membuka akses masyarakat terhadap lahan seluas 2.216 .225 hektar melalui PHBM dari luas wilayah kerjanya yang terdiri 2,5 juta hektar (Perhutani, 2016). Kerjasama pengelolaan ini melibatkan sebanyak 5.278 desa (97\%) dari 5.386 desa di Pulau Jawa dan Madura yang berada di sekitar kawasan hutan (Tabel 1).

Kementerian Kehutanan tercatat mengeluarkan keputusan menteri pada tahun 2001 terkait hutan kemasyarakatan dan satu peraturan menteri pada tahun 2004 terkait pemberdayaan masyarakat. Namun belum ditemukan catatan pencapaian hasil dari kebijakan tersebut (Tabel 1).

Target program perhutanan sosial yang dicanangkan dalam rencana pembangunan jangka menengah nasional-RPJMN 20102014 seluas 2,5 juta hektar (Purwanto, 2017). Capaian program perhutanan sosial pada periode tahun 2007 sampai 2016 dalam bentuk HKm, HD, HTR, dan Kemitraan mencapai luas 607.269,63 hektar (Tabel 4).

Tabel 4. Rekapitulasi perizinan perhutanan sosial tahun 2007- november 2016

\begin{tabular}{|c|c|c|}
\hline No & Perizinan & Luas (Hektar) \\
\hline 1 & HPHD & $471.451,00$ \\
\hline 2 & IUP HKm & $432.613,36$ \\
\hline 3 & IUPHHK HTR & $768.859,73$ \\
\hline 4 & MoU Kemitraan Kehutanan & $44.010,16$ \\
\hline & Total & $607.269,63$ \\
\hline
\end{tabular}

\subsection{Target dan Capaian Perhutanan Sosial Setelah Tahun 2016}

Target perhutanan sosial dalam bentuk HKm, HD, HTR, Kemitraan dan HA yang dituangkan dalam RPJMN 2015-2019 adalah seluas 12,7 juta hektar akses lahan untuk masyarakat. Saat ini telah diterbitkan Peta Indikatif Areal Perhutanan Sosial (PIAPS) seluas 12.739.224 hektar pada 22 Oktober 2015 (Purwanto, 2017). Luasan ini adalah akumulasi dari hutan produksi (HP) yang tidak dibebani ijin seluas 4.545.797 ha, usulan hutan adat hasil registrasi Badan Registrasi Wilayah Adat-BRWA dan Aliansi Masyarakat Adat Nusantara-AMAN seluas 3.921.841 ha, hasil pemetaan partisipatif Jaringan Kerja Pemetaan Partisipatif (JKPP) seluas 595.659 ha, hasil identifikasi dan pendataan KpSHK seluas 1.607.877 ha, lokasi yang tidak termasuk tanah obyek reforma agraria (TORA) di Provinsi Kalimantan Selatan (Kalsel), Nusa Tenggara Barat (NTB), Lampung dan Bali seluas 197.310 ha, dan areal yang sedang berproses dan usulan Balai Pengelolaan Daerah Aliran Sungai (BPDAS) seluas 1.870.740 ha). PIAPS ini diinisiasi oleh Direktorat Perhutanan Sosial dan Kemitraan Lingkungan (PSKL). Ditjen PSKL didukung data oleh BRWA/AMAN dan Konsorsium Pendukung Sistem Hutan Kerakyatan (KpSHK).

Peta PIAPS dapat diakses pada laman Kementerian Lingkungan Hidup dan Kehutanan. Salah satu contoh cuplikan peta PIAPS lembar 192 yang juga memuat peta lokasi studi sebagaimana pada Gambar 2. 


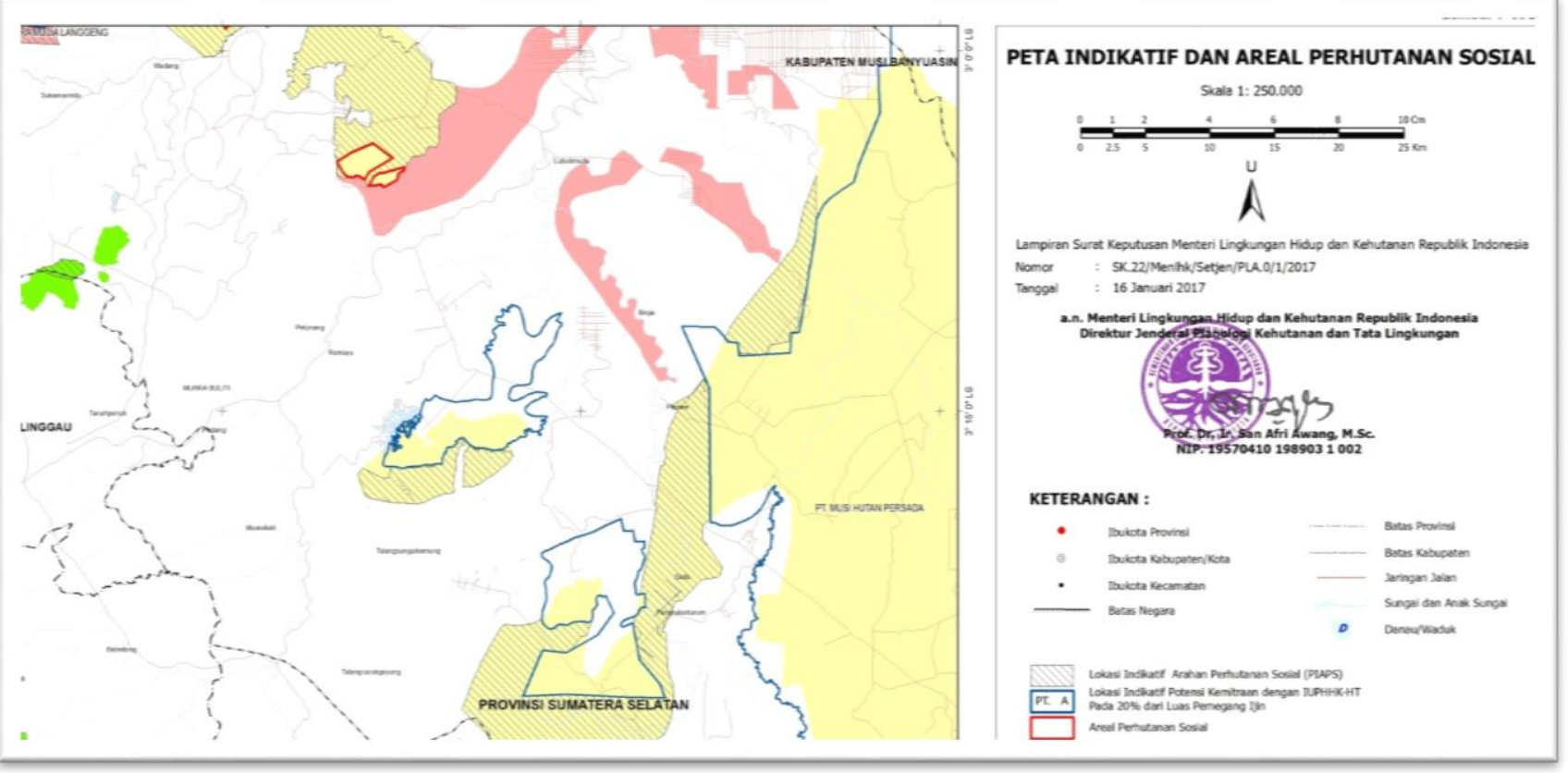

Gambar 2. Cuplikan peta PIAPS dan lokasi studi kasus

\subsection{Peran Perhutanan Sosial dalam Meningkatkan Kesejahteraan Masyarakat}

Peran perhutanan sosial dalam meningkatkan kesejahteraan dapat dicermati berdasarkan manfaat yang dirasakan masyarakat dalam meningkatkan ekonomi dan ekologi yakni dalam menuju perwujudan masyarakat sejahtera dan hutan lestari. Secara ekonomi perhutanan sosial melalui PHMB di Perhutani diklaim mampu menyerap tenaga kerja sebanyak 6.304 .467 orang dengan nilai sebesar Rp.705,71 miliar. Pendapatan Perhutani yang berasal dari skema bagi hasil produksi kayu dan non kayu adalah sebesar Rp.252,34 miliar periode tahun 2002 sampai dengan 2012. Pendapatan yang berasal dari produksi tanaman pangan yang ditanam dalam kegiatan tumpangsari mencapai Rp.7.469,09 miliar atau rata-rata Rp.679,01 miliar per tahun (Perhutani, 2016). Selain kesejahteraan, manfaat PHBM dirasakan oleh masyarakat adalah eksistensi hutan terjaga sesuai dengan kaidah-kaidah silvikultur dan konservasi dan hutan tetap lestari (Perhutani, 2016).

Nilai ekonomi dari perhutanan sosial, yang telah berjalan sejak tahun 2015, belum semua dapat dirasakan langsung oleh masyarakat. Pada HKm Wana Manunggal pendapatan dari HHBK dan pendapatan dari wisata alam telah dapat dirasakan masyarakat. Sementara pada HD di desa Muara Megang-1 saat ini belum dirasakan manfaat ekonomi hasil budidaya tanaman. Nilai ekonomi yang ada masih bersifat potensial dalam bentuk tanaman yang dalam beberapa tahun kemudian akan memberikan hasil (Tabel 1). Dari sisi lingkungan atau kelestarian hutan, catatan pada lokasi studi kasus menunjukkan bahwa baik di HKm maupun di HD terdapat peningkatan variasi jenis tanaman dan tutupan lahan (Tabel 1).

Dari catatan hasil PS baik di Perhutani maupun pada lokasi studi menunjukkan hasil adanya peningkatan pendapatan masyarakat baik yang telah dirasakan maupun masih potensial. Sedangkan dari segi kelestarian hutan peningkatan jumlah jenis tanaman dan penutupan lahan ditemukan baik di Perhutani maupun pada program HKm dan HD di lokasi studi. Dengan demikian tanda-tanda adanya peningkatan kesejahteraan dan peningkatan kelestarian hutan telah ditemui. Oleh karena itu program ini optimis akan dapat mewujudkan "Masyarakat Sejahtera dan Hutan Lestari".

\subsection{Peran Perhutanan Sosial dalam Mengurangi Konflik Tenurial}

Dari segi sosial, PHMB di Perhutani dinyatakan mampu menyerap tenaga kerja sebanyak 6.304 .467 orang dengan nilai sebesar Rp.705,71 miliar dalam kurun waktu 2001 sampai dengan 2012. PHBM juga dinyatakan mampu mendorong kesempatan berusaha di berbagai sektor, yakni industri sebanyak 3.655 unit usaha, perdagangan 3.775 unit usaha, pertanian 1.347 unit usaha, peternakan 2.737 unit usaha, perkebunan 95 unit usaha, perikanan 482 unit usaha, jasa 1.888 unit usaha, dan 76 unit usaha lainnya (Perhutani, 2016). Manfaat sosial ini dipandang dapat mengurangi keinginan untuk menambah lahan garapan yang menjadi salah satu penyebab timbulnya konflik tenurial.

Peran HKm dan HD pada lokasi studi terhadap konflik tenurial yang sebelumnya dirasakan adalah dapat memberikan rasa aman dan ketenangan dalam beraktivitas di dalam kawasan hutan. Kegiatan pemanfaatan lahan pada kawasan hutan sekarang telah legal dengan adanya Ijin Usaha Pengelolaan Hutan Kemasyarakatan (IUP HKm) dan Hak Pengelolaan Hutan Desa (HPHD). Pada HD di lokasi studi tercatat dapat mempengaruhi gaya sengketa desa lain. Desa Jajaran Baru-II, yang berbatasan dengan desa Muara Megang-1, saat ini berubah gaya sengketanya dari gaya kompetisi, pada tahun 2012, menjadi kompromi. Gaya kompromi ini ditunjukkan dengan sikapnya yang memutuskan bekerjasama dengan KPH Unit 13 Lakitan Bukit Cogong dalam pengelolaan kawasan hutan. Perubahan gaya sengketa ini terjadi setelah melihat desa-desa yang telah memiliki HPHD memperoleh banyak program yang menguntungkan dari KPH Lakitan.

\subsection{Hambatan Perhutanan Sosial di Lapangan}

Beberapa hal yang dicatat masih menjadi hambatan dalam pelaksanaan perhutanan sosial baik di lokasi studi maupun lokasi tambahan lainnya adalah: a) hasil kayu terlalu lama, b) hak garap dipindah tangan ke orang luar desa, c) kepemilikan hak garap lebih dari satu, d) ada konflik kepengurusan yang mengakibatkan penelantaran pengelolaan perhutanan sosial, e) batas wilayah kelola di lapangan belum ada, f) batas wilayah HD berada di luar wilayah desa, g) batas wilayah administrasi desa belum disepakati desa tetangga, h) belum dianggarkan biaya penataan batas HD, i) belum ada dana di KPH untuk membeli getah karet hasil kemitraan, dan j) adanya larangan membukaan lahan dengan cara membakar. 


\subsection{Faktor Pendukung Kesuksesan Perhutanan Sosial}

Konsistensi kebijakan pemerintah dan peran serta berbagai pihak termasuk lembaga non pemerintah merupakan kunci penting keberhasilan pelaksanaan perhutanan sosial. Situasi politik menjelang pemilihan umum setelah periode tahun 2019 juga diperhitungkan sebagai faktor pendorong pencapaian target perhutanan sosial mengingat pemerintah periode 2014-2019 tentu ingin memberikan kesan berpihak terhadap masyarakat.

\subsection{Pandangan Islam Terhadap Perhutanan Sosial di Indonesia}

Islam memandang bahwa hutan merupakan masuk kedalam kategori kepemilikan umum dan bukan kepemilikan individu atau negara. Nabi Muhammad SAW. bersabda: "Kaum Muslim bersekutu (sama-sama memiliki hak) dalam tiga hal: air, padang rumput dan api" (HR Abu Dawud dan Ibn Majah). Penjelasan Hadits di atas menunjukkan bahwa air (sumber mata air), padang rumput (hutan) dan api (bahan tambang minyak dan bijih) adalah milik umum, karena sama-sama mempunyai sifat tertentu sebagai illat (alasan penetapan hukum), yakni menjadi hajat hidup orang banyak. Kepemilikan umum sebagai izin Allah (selaku pembuat hukum) kepada jamaah (masyarakat) untuk memanfaatkan benda secara bersama-sama (An-Nabhani, 2009). Dengan penjelasan ini perhutanan sosial di Indonesia dengan skema HD, HKm, HTR, Kemitraan, dan HA semua memenuhi kriteria dimiliki hak kelola secara bersama-sama. Meskipun demikian, ada satu catatan kecil pada skema HTR yang yang memungkinkan hak kelolanya boleh dimiliki perorangan. Islam memandang bahwa yang berhak mengelola hutan yaitu negara dan bukan swasta baik swasta individu, kelompok atau perusahaan baik dalam negeri maupun swasta asing (Widodo, 2009). Aset yang tergolong kepemilikan umum ini, tidak boleh sama sekali dimiliki secara individu atau dimonopoli oleh sekelompok orang.

\section{KESIMPULAN}

Kebijakan perhutanan sosial dapat dicatat dalam beberapa fase. Fase pertama adalah kebijakan yang dikeluarkan oleh Direktur Perum Perhutani dalam bentuk Keputusan Direktur pada periode tahun 2007 sampai dengan 2011. Pada kementerian kehutanan keputusan menteri dikeluarkan sejak tahun 2001 terkait hutan kemasyarakatan kemudian pada tahun 2004 terkait pemberdayaan masyarakat dalam rangka social forestry. Periode 2007 sampai dengan 2014 diterbitkan peraturan menteri kehutanan, yang beberapa kali diubah, yang mengatur HKm, HD, HTR, dan Kemitraan masing-masing secara terpisah. Pada tahun 2016 peraturan menteri LHK nomor 83 tahun 2016 mengatur HD, HKm, HTR, Kemitraan, dan Hutan Adat dalam satu peraturan.

Program perhutanan sosial sejak Perhutani berdiri, berevolusi dari program Mantri-Lurah pada tahun 1972, Perhutanan Sosial tahun 1984, Pembinaan Masyarakat Desa Hutan Terpadu (PMDHT) tahun 1994, PMDH tahun 1988, PHBM tahun 2001, dan PHBM Plus dari tahun 2001 sampai dengan 2016. Program perhutanan sosial pada kementerian kehutanan mulai dengan nama Hutan Kemasyarakatan pada tahun 2001. Program HD, HKm, dan HTR lahir pada tahun 2007, sementara Kemitraan lahir pada tahun 2013. Program perhutanan sosial terakhir yang muncul selain HD, HKm, HTR, dan Kemitraan, berdasarkan P.83 tahun 2016, adalah Hutan Adat.

Perhutanan sosial yang dilakukan Perhutani, sejak tahun 2001 sampai tahun 2012 melalui PHBM, telah membuka akses masyarakat terhadap lahan seluas 2.216.225 hektar. Perhutanan sosial pada kementerian LHK yang ditargetkan 2,5 juta ha pada 2010-2014 tercapai 607.269,63 hektar pada akhir tahun 2016 melalui program HD, HKm, HTR, dan Kemitraan. Target perhutanan sosial pada 2015 sampai 2019 adalah 12,7 juta hektar yang masih dalam proses pencapaiannya dari PIAPS yang telah disiapkan oleh Ditjen PSKL.

Peran perhutanan sosial dirasakan dapat meningkatkan pendapatan baik yang telah dirasakan maupun yang masih potensial di lapangan. Dari sisi kelestarian hutan perhutanan sosial dapat meningkatkan variasi jenis tanaman dan meningkatkan penutupan lahan. Perhutanan sosial dinyatakan dapat mengurangi konflik tenurial melalui penyerapan tenaga kerja, pemberian rasa aman dan pemberian ketenangan berusaha pada kawasan hutan karena telah memiliki legalitas pengelolaan.

Dari sudut pandang Islam skema perhutanan sosial setelah tahun 2016 telah memenuhi kriteria pemegang hak kelolanya adalah masyarakat umum kecuali HTR yang mengijinkan perorangan memegang hak kelola.

\section{UCAPAN TERIMA KASIH}

Terima kasih penulis sampaikan kepada Kepala Balai Diklat Lingkungan Hidup dan Kehutanan Kadipaten yang telah mengijinkan dan mendukung penelitian ini. Kepada para informan yang telah memberikan informasi berharga kami ucapkan terima kasih. Kepada panitia Seminar Nasional Peduli Negeri penulis ucapkan terima kasih atas kesempatan untuk memaparkan tulisan ini. Kepada pengelola Jurnal Kajian Peradaban Islam kami ucapkan terima kasih atas dipertimbangkannya tulisan ini sebagai salah satu tulisan untuk dipublikasikan.

\section{Daftar Pustaka}

Abdullah, I. (2017, April 10). Mengkaji Program Distribusi Lahan. Retrieved Juli 31, 2017, from http://www.harnas.co: http://www.harnas.co/2017/04/09/mengkaji-program-distribusi-lahan

An-Nabhani, T. (2009). Sistem Ekonomi Islam.(Judul Asli : An-Nizham al-Iqtishadi fi al-Islam, Beirut : Darul Ummah, 1990). Bogor: Al Azhar.

Anton, R. (2015, November 20). Jumlah Penduduk Indonesia Sudah 254,9 Juta, Laki-laki Lebih Banyak Dari Perempuan. Retrieved Juli 18, 2017, from https://www.hidayatullah.com: https://www.hidayatullah.com/berita/nasional/read/2015/11/20/83632/jumlah-pendududari-perempuan.html

Asropi. (2016). Analisis Penelitian Modul Diklat Kewidyaiswaraan Berjenjang Tingkat Menengah. Jakarta: Lembaga Administrasi Negara RI.

Astuti, K. D. (2016, Juni 13). 100.000 Hektare Lahan Pertanian Menyusut Setiap Tahun. Retrieved Juli 19, 2017, from http://www.pikiran-rakyat.com: http://www.pikiran-rakyat.com/jawa-barat/2016/06/13/100000-hektare-lahanpertanian-menyusut-setiap-tahun-371703

Badan Informasi Geospasial. (2013, Pebruari 01). BIG Serahkan Peta NKRI Kepada Kemenkokesra. Retrieved July 18, 2017, from http://www.bakosurtanal.go.id: http://www.bakosurtanal.go.id

BPS. (2009). Statistik Indonesia 2009. Jakarta: Badan Pusat Statistik.

BPS. (2014). Buku Statistik Indonesia 2014. Jakarta: BPS. 
BPS. (2017, Pebruari 08). Luas Kawasan Hutan dan Kawasan Konservasi Perairan Indonesia Menurut Provinsi Berdasarkan SK Menteri Kehutanan. Retrieved July 07, 2017, from https://www.bps.go.id: https://www.bps.go.id/linkTabelStatis/view/id/1716

Destrianita. (2017, Juli 17). Maret 2017, Jumlah Penduduk Miskin Indonesia Capai 27,77 Juta. Retrieved Juli 31, 2017, from https://bisnis.tempo.co: https://bisnis.tempo.co/read/news/2017/07/17/090892130/maret-2017-jumlah-pendudukmiskin-indonesia-capai-27-77-juta

Djamhuri, T. L. (2008). Community participation in a social forestry program in Central Java, Indonesia: the effect of incentive structure and social capital. Agroforest Syst, 74, 83-96.

Gamin., Nugroho, B., Kartodihardjo, H., Kolopaking, L. M., \& Boer, R. (2014). Menyelesaikan Konflik Penguasaan Kawasan Hutan Melalui Pendekatan Gaya Sengketa Para Pihak di Kesatuan Pengelolaan Hutan Lakitan. Jurnal Analisis Kebijakan Kehutanan, 11(1), 71-90.

Handoyo, Suka, A., \& Ginoga, K. (2011). Identifkiasi Tenurial sebagai Pra-Kondisi Untuk Implementasi REDD+. J. Penelitian Sosial Ekonomi Kehutanan. 8(4), 306-320.

Hayami, Y., \& Otsuka, K. (1993). The Economics of Contract Choice: An Agrarian Perspective. Oxford (GB): Clarendon Press.

Hu, W. (1997). Household land tenure reform in China: its impact on farming land use and agroenvironment. Land Use Policy, $14(3), 175-186$.

Irawan, P. (2006). Penelitian Kulitatif \& Kuantitatif Untuk Ilmu-Ilmu Sosial. Jakarta: Departemen Ilmu Administrasi Fakultas Ilmu Sosial dan Ilmu Politik, Universitas Indonesia.

Kant, S., \& Cooke, R. (1999). Jabalpur District, Madhya Pradesh, India: Minimizing Conflict in Joint Forest Management. . Retrieved from http://www.idrc.ca.

Kartodihardjo, H. (2011, November 21-24). Penanganan Konflik Kehutanan: Peran dan Pengalaman Dewan Kehutanan Nasional. Forum DKN Untuk Mediasi Konflik. Jakarta, DKI Jakarta: Konggres Kehutanan Indonesia (KKI) ke V. Gd. Manggala Wana Bhakti Jakarta.

KemenLHK. (2016). Kegiatan Penyiapan Kawasan Perhutanan Sosial Tahun 2007-November 2016. Jakarta: Direktorat Penyiapan Kawasan Perhutanan Sosial Kementerian Lingkungan Hidup dan Kehutanan.

Khan, N. A. (1998). Land tenurial dynamics and participatory forestry. Public Admin. Dev, 18(4), 335-347.

Nasir, A., Saleh, M. B., \& Bahruni. (1997, April). Optimalization of Land Use Collaborative Management Model Perum Perhutani: Study Case KPH Pekalongan Barat. Jurnal Manajemen Hutan Tropika, 23(1), 25-36.

Nurbaya, S. (2015, Desember 14). Arahan Menteri Rakornas KLHK 2014, 17Des14. Jakarta, DKI Jakarta, DKI Jakarta.

Pemprov Sumsel. (2015, Desember 1). Keputusan Gubernur Sumatera Selatan Nomor:858/KPTS/DISHUT/2015. Pemberian Hak Pengelolaan Hutan Desa Kepada Lembaga Pengelola Hutan Desa Muara Megang I pada Kawasan Hutan Produksi Tetap Seluas +/- 764 Hektar di Kecamatan Mengang Sakti Kabupaten Musi Rawas. Palembang, Sumatera Selatan, Indonesia: Pemerintah Daerah Provinsi Sumatera Selatan.

Perhutani. (2016, - -). Pengelolaan Hutan Bersama Masyarakat (PHBM). Retrieved September 7, 2017, from http://www.bumn.go.id: http://www.bumn.go.id/perhutani/halaman/159

PSKL. (2017). Tentang Program Perhutanan Sosial. Retrieved Juli 31, 2017, from http://pskl.menlhk.go.id: http://pskl.menlhk.go.id/akps/index.php/site/cara_pendaftaran

Purwanto, E. (. (2017). Tantangan Perhutanan Sosial dan peran CSO. Prosiding Lokakarya "Strategi Penguatan Perhutanan Sosial dan Peran CSO", Bogor, 22-23 October 2015. Bogor: Tropenbos Indonesia.

Singh, K. (2000). A Evaluation of Some Selected Social Forestry Models Adpten di India. Ind.Jn of Agri.Con, 55(3), 421-434.

Singh, P., Mahankuda, P. K., Dolai, S. K., Behera, B. C., \& Choudhury, A. K. (2016, July). Estimating Economic Benefits Through Social Forestry in Odisha. Splint International Juournal of Profesionals, 3(7), 59-66.

Sugiyono. (2010). Memahami Penelitian Kualitatif. Bandung: Alfabeta.

Thompson, H. (1999). Social Forestry: An Analysis of Indonesian Forestry Policy. Journal of Contempory Asia, 29 (2), $187-201$.

UNDP. (2017, Maret 22). Indeks Pembangunan Manusia Indonesia Meningkat tapi Kesenjangan Masih Tetap Ada. Retrieved Juli 31, 2017, from www.id.undp.org: http://www.id.undp.org/content/indonesia/id/home/presscenter/pressreleases/2017/03/22/indonesia-s-humandevelopment-index-rises-but-inequality-remains-.html

Widodo. (2009, April). Pengelolaan Hutan Dalam Islam dan Implikasinya Terhadap Kehidupan Masyarakat. Retrieved April 23, 2018, from http://risetfossei.blogspot.co.id: http://risetfossei.blogspot.co.id/2009/04/pengelolaan-hutan-dalam-islamdan.html

Yin, R. K. (1996). Studi Kasus, Desain \& Metode. Jakarta: PT. Raja Grafindo Persada. 